\title{
AIR POLLUTION TOLERANCE INDEX OF WHEAT AND RICE IN THE PROXIMITY OF GAS BASED POWER PLANT
}

\author{
Priya Choudhary $^{1^{*}}$, Shakeel Ahmad Khan ${ }^{2 *}$, Ambrina Sardar Khan ${ }^{1}$, \\ Sandeep Kumar², Lal Chand Malav ${ }^{3}$
}

\footnotetext{
${ }^{1}$ AmityInstitute of Environmental Sciences, Amity University, Noida, Uttar Pradesh, India

${ }^{2}$ IndianCouncil of Agricultural Research-Indian Agricultural Research Institute, New Delhi, India

${ }^{3}$ Indian Council of Agricultural Research-National Bureau of Soil Survey \& Land Use Planning, Nagpur, Maharashtra, India
}

Received - September 21, 2021; Revision - December 05, 2021; Accepted - December 11, 2021

Available Online - December 30, 2021

DOI: http://dx.doi.org/10.18006/2021.9(6).791.804

\section{KEYWORDS}

Rice

Wheat

APTI

Biochemical parameters

Air pollutants

\begin{abstract}
The study aimed to identify the tolerance level of rice and wheat due to air pollutants around the gasbased power plant. Ten sites were selected around $10 \mathrm{~km}$ radius of gas based power plant. Major air pollutants like $\mathrm{NO}_{\mathrm{x}}, \mathrm{SO}_{\mathrm{x}}$, ozone, and $\mathrm{PM}_{10}$ were monitored in ten sites during the growth of rice and wheat. The Air Quality Index (AQI) of villages falls mostly in the category of moderately polluted sites. Air Pollution Tolerance Index (APTI) is a tool applied for categorizing sensitive or tolerant plants towards air pollution and is calculated by using four biochemical parameters like total chlorophyll content, ascorbic acid, $\mathrm{pH}$, and relative water content of rice and wheat. Results indicated that the $\mathrm{pH}$ of cell sap of both the crops was acidic to neutral $\mathrm{pH}$ (3.5-6.9) at polluted sites while neutral to slightly alkaline (7.0-7.9) at less polluted sites. Ascorbic acid content was high at polluted sites since ascorbic acid shows a defense mechanism against air pollution. Chlorophyll content (up to $0.61 \mathrm{mg} / \mathrm{g}$ ) and relative water content have shown a significant decrease at most polluted sites. As per APTI values (APTI<11), both the crops were sensitive to air pollution in the selected area. APTI might be beneficial in the selection of crop species in the polluted area which shows that a higher concentration of air pollutants can damage crops severely. APTI was found to be positively correlated with $\mathrm{pH}$, total chlorophyll content, and relative water content and negatively correlated with ascorbic acid.
\end{abstract}

* Corresponding author

E-mail: priyaenvi91@gmail.com (Priya Choudhary); shakeel_iari@yahoo.com (Shakeel Ahmad Khan)

Peer review under responsibility of Journal of Experimental Biology and Agricultural Sciences.

Production and Hosting by Horizon Publisher India [HPI] (http://www.horizonpublisherindia.in/).

All rights reserved.
All the articles published by Journal of Experimental Biology and Agricultural Sciences are licensed under a Creative Commons Attribution-NonCommercial 4.0 International License Based on a work at www.jebas.org.

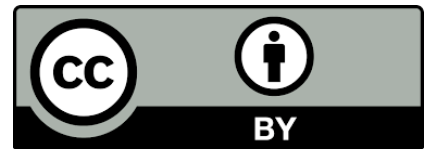




\section{Introduction}

The urban air quality of India has been severely affected by increased urbanization, vehicular traffic, industrialization, unplanned development of the city, and population growth. Urbanization has negative environmental repercussions, including increased air pollution, which has concerns for public health and harms the ecosystem (Bui et al., 2021). According to WHO (2018) report, India has 9 out of 10 most air-polluted cities in the world. Air quality monitoring stations in many cities of India show poor Air Quality Index (AQI) and concentration of particulates exceeds the ambient air quality guideline value. Some of the important air pollutants are oxides of nitrogen, ozone, and particulate matter. Their release from different kinds of sources exacerbates the ambient air quality and causes threats to the crops grown in the vicinity of the source (Achakzai et al., 2017; Malav et al., 2017). Particulates and gaseous pollutants affect the morphological features, biochemical parameters, and yield of crops (Chauhan \& Joshi, 2010). The profound effects are significant in restriction of physiological processes, a decrease of photosynthetic pigments, change in metabolic roles and enzymes activities of plants (Musselman et al., 2006).

Monitoring biochemical parameters such as leaf $\mathrm{pH}$, ascorbic acid concentration, total chlorophyll content, and relative water content can be used to determine the impact of air pollution on plants (Kuddus et al., 2011). The air pollution tolerance index (APTI) is a tool that is computed by these parameters and is used to assess the tolerance level of plant species towards air pollution (Nayak et al., 2015). Various APTI studies have been done on plants and tree species but very few investigations have been done on crops particularly rice and wheat (Sisodia \& Dutta, 2016). APTI of crops will help in determining the severity of damage due to air pollution. The present study was conducted in Faridabad to evaluate the Air Pollution Tolerance Index (APTI) of rice and wheat have grown around gas based power plants.

\section{Materials and Methods}

\subsection{Study Area}

Faridabad $\left(28.4089^{\circ} \mathrm{N}\right.$ latitude, $77.3178^{\circ} \mathrm{E}$ longitude; Area $742.9 \mathrm{~km}^{2}$ ) is considered as the industrial hub of Haryana (Figure 1). The terrain is plain with Yamuna River on its east. It experiences hot summer and cold winter with unpredictable rainfall patterns. The soils in the study area are loam and sandy loam while in the Yamuna region, the soil is loam and silty loam. The study area is National Thermal Power Corporation (NTPC) $\left(28.3485^{\circ} \mathrm{N}\right.$ latitude, $77.3622^{\circ} \mathrm{E}$ longitude) located in Mujedi village, Faridabad. It is gas based power plant with a combined cycle having a capacity of $432 \mathrm{MW}$. The fuel gases used for the generation of electricity are natural gas and naphtha. The villages are selected around a $10 \mathrm{~km}$ radius of NTPC. The sites were selected in North, East, West, and South direction at different distances in reference with NTPC. Most of the time, the direction of the wind was westerly so the sites were selected towards the east of North and South. The control site was in the West direction since there was no primary source of air pollution. Ten villages that have been selected for study are Mujedi, Faridpur, Sadupura, Bhuapur, Tigaon, Mandhawali, Gharora, Badraula, Khera, and Ghazipur as shown in Figure 2. The description of the study site with latitude, longitude, and distance from NTPC is given in Table 1. NTPC is located in Mujedi village and Ghazipur is taken as a control site. The major crops grown around this region are rice and wheat. In Faridabad, Air Quality Index (AQI) showed moderately polluted air quality (101-200) with $\mathrm{PM}_{10}$ exceeding the standard limit $\left(100\left(\mu \mathrm{g} / \mathrm{m}^{3}\right)\right.$ (Garg et al., 2021).

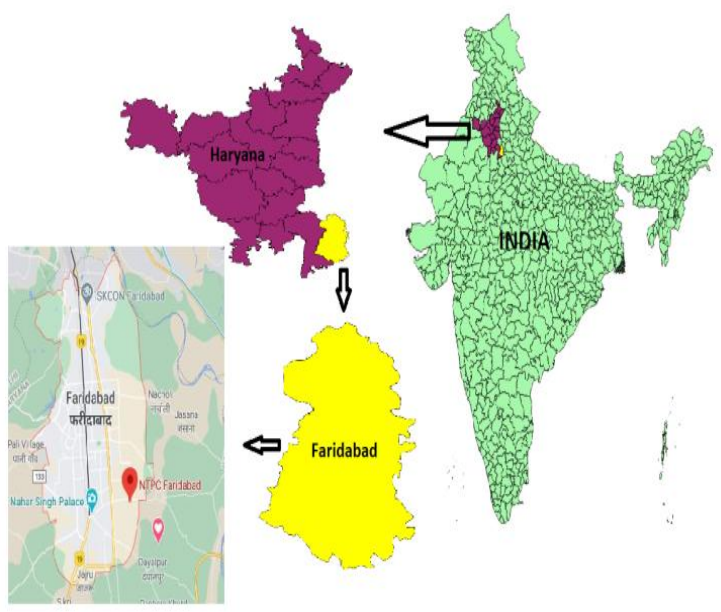

Figure 1 Map of the study site

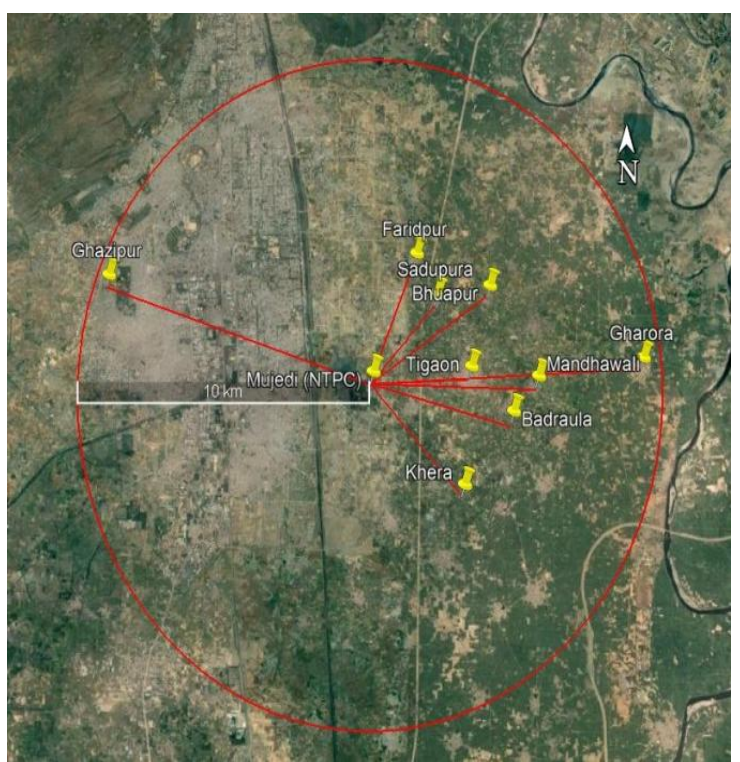

Figure 2 Ten villages selected for the study. 
Table 1 Description of study sites (Direction and distance is in reference with NTPC)

\begin{tabular}{|c|c|c|c|c|c|}
\hline Site No. & Villages & Latitudes & Longitudes & Direction & Distance $(\mathrm{km})$ \\
\hline 1. & Mujedi & $28.20^{\prime} 54.8^{\prime \prime} \mathrm{N}$ & $77.21^{\prime} 44.2$ " E & Centre & 0.30 \\
\hline 2. & Faridpur & $28^{\circ} 22^{\prime} 45.5^{\prime \prime} \mathrm{N}$ & $77^{\circ} 22^{\prime} 39.8^{\prime \prime} \mathrm{E}$ & North East & 3.8 \\
\hline 3. & Sadupura & $28^{\circ} 22^{\prime} 20.7^{\prime \prime} \mathrm{N}$ & $77^{\circ} 23^{\prime} 00.7^{\prime \prime E}$ & North East & 3.35 \\
\hline 4. & Bhuapur & $28^{\circ} 22^{\prime} 12.3^{\prime \prime} \mathrm{N}$ & $77^{\circ} 24^{\prime} 08.1^{\prime \prime} \mathrm{E}$ & East North East & 4.8 \\
\hline 5. & Tigaon & $28^{\circ} 20^{\prime} 44.6^{\prime \prime} \mathrm{N}$ & $77^{\circ} 23^{\prime} 15.6 " \mathrm{E}$ & East & 3.35 \\
\hline 6. & Mandhawali & $28^{\circ} 20^{\prime} 42.4^{\prime \prime} \mathrm{N}$ & $77^{\circ} 25^{\prime} 02.0^{\prime \prime} \mathrm{E}$ & East & 5.6 \\
\hline 7. & Gharora & $28^{\circ} 21^{\prime} 05.7^{\prime \prime} \mathrm{N}$ & $77^{\circ} 27^{\prime} 17.1^{\prime \prime} \mathrm{E}$ & East & 9.2 \\
\hline 8. & Badraula & $28^{\circ} 20^{\prime} 22.6^{\prime \prime} \mathrm{N}$ & $77^{\circ} 24^{\prime} 52.3^{\prime \prime} \mathrm{E}$ & East South & 4.92 \\
\hline 9. & Khera & $28^{\circ} 19^{\prime} 14.8^{\prime \prime} \mathrm{N}$ & $77^{\circ} 23^{\prime} 41.8^{\prime \prime} \mathrm{E}$ & South East & 4.46 \\
\hline 10. & Ghazipur & $28^{\circ} 22^{\prime} 26.8^{\prime \prime N} \mathrm{~N}$ & $77^{\circ} 16^{\prime} 10.3 " \mathrm{E}$ & West & 9 \\
\hline
\end{tabular}

\subsection{Air Quality Analysis}

The ambient air quality was monitored for all the ten sites as per CPCB Guidelines (2011). Air sampling for $\mathrm{SO}_{2}, \mathrm{NO}_{2}$, and $\mathrm{PM}_{10}$ was done for 24 hours per month (i.e., 1 day per month) at each of the sites during the growth of rice and wheat while for ozone 8 hours sampling was done as per the CPCB guidelines (2011).

Respirable Dust Sampler (Envirotech APM460BL) instrument was used for the monitoring of these pollutants. $\mathrm{NO}_{2}$ was analyzed by Jacob and Hochheiser method (Jacob \& Hochheiser, 1958), while $\mathrm{SO}_{2}$ was analyzed by Improved West and Gaeke method (West \& Gaeke, 1956), and $\mathrm{O}_{3}$ was measured by chemical method and $\mathrm{PM}_{10}$ by gravimetric method. Air Quality Index was computed by using these three air parameters (Rao \& Rao, 1998). The formula used was:

$\mathrm{AQI}=1 / 3\left(\mathrm{O}_{3} / N A A Q S_{\mathrm{O}_{3}}+\mathrm{NO}_{2} / N A A Q S_{\mathrm{NO} 2}+\mathrm{PM} 10 / N A A Q S_{\mathrm{PM} 10}\right) \times 100$

Where $\left(\mathrm{O}_{3}\right),\left(\mathrm{NO}_{2}\right)$ and $\left(\mathrm{PM}_{10}\right)$ represent the individual concentration $\left(\mu \mathrm{g} / \mathrm{m}^{3}\right) ; \quad \mathrm{NAAQSo}_{3}, \quad \mathrm{NAAQS}_{\mathrm{NO} 2}, \quad \mathrm{NAAQS}_{\mathrm{PM} 10}$ represents the ambient air quality standards for $\mathrm{O}_{3}, \mathrm{NO}_{2}$ and Particulate Matter $\left(\mathrm{PM}_{10}\right)$, respectively.

National Ambient Air Quality Standards (NAAQS) used in the above formula for the calculation of AQI are shown in Table 2.

Table 2 National Ambient Air Quality Standard (NAAQS) for air pollutants

\begin{tabular}{|ccc|}
\hline S.No. & Air Pollutant & NAAQS $\left(\mu \mathrm{g} / \mathrm{m}^{3}\right)$ \\
\hline 1. & $\mathrm{O}_{3}$ & 100 \\
\hline 2. & $\mathrm{NO}_{2}$ & 80 \\
\hline 3. & Particulate Matter $\left(\mathrm{PM}_{10}\right)$ & 100 \\
\hline
\end{tabular}

\subsection{Sampling of crops}

Leave samples of Oryza sativa (Rice) and Triticum aestivum (Wheat) were collected from ten villages in Faridabad. The samples were collected in zipper polythene bags and brought to the laboratory for further analysis. Fresh leave weight was measured immediately and biochemical analysis was performed on the same day.

\subsection{Analysis of biochemical parameter}

\subsection{1 pH}

$4 \mathrm{gm}$ of leaf sample was homogenized in $40 \mathrm{ml}$ of deionized water. It was centrifuged at $7000 \mathrm{~g}$ and the extract was analyzed by $\mathrm{pH}$ meter after its calibration with a buffer solution of $\mathrm{pH} 4$ and 9 (Liu \& Ding, 2008).

\subsubsection{Relative Water Content (RWC)}

RWC calculates the present water content of the leaf tissue tested in comparison to the maximum water content it can retain at full turgidity. The balance between water supply to the leaf tissue and transpiration rate is reflected in the relative water content (RWC) of leaves, which is an essential measure of water status in plants. It was analyzed by using the procedure of Singh (1977).

$$
\operatorname{RWC}(\%)=\left(\mathrm{W}_{\mathrm{F}}-\mathrm{W}_{\mathrm{D}}\right) \times 100 /\left(\mathrm{W}_{\mathrm{T}}-\mathrm{W}_{\mathrm{D}}\right)
$$

$\mathrm{W}_{\mathrm{F}^{-}}$weight of fresh leaves; $\mathrm{W}_{\mathrm{T}^{-}}$Turgid weight is the weight after immersing the leaves in water overnight and then blotted dry in air; $\mathrm{W}_{\mathrm{D}^{-}}$Dry Weight is obtained by drying the leaves at $70^{\circ} \mathrm{C}$ in the oven for overnight and then measuring the weight.

\subsubsection{Ascorbic Acid content (AA)}

Ascorbic acid of leaf samples was examined by the method of Keller \& Schwager (1977). The leaf samples were extracted by 
oxalic acid and EDTA. The solution was centrifuged and the collected supernatant was mixed with 2,6dichlorophenolindophenol (DCPIP). Then optical density (OD) of the pink color mixture was measured at $520 \mathrm{~nm}\left(\mathrm{OD}_{\mathrm{s}}\right)$. Then, ascorbic acid was added to the mixture and the pink color was disappeared. OD of the final solution $\left(\mathrm{OD}_{\mathrm{t}}\right)$ and DCPIP $\left(\mathrm{OD}_{\mathrm{o}}\right)$ was recorded at the same wavelength $\left(\mathrm{OD}_{\mathrm{s}}\right)$.

$$
\mathrm{AA}(\mathrm{mg} / \mathrm{g})=\mathrm{V}_{\mathrm{T}} \times\left[\mathrm{OD}_{\mathrm{o}}-\left(\mathrm{OD}_{\mathrm{s}}-\mathrm{OD}_{\mathrm{t}}\right)\right] / \mathrm{V}_{\mathrm{S}} \times \mathrm{W}_{\mathrm{f}} \times 1000
$$

Where, $\mathrm{W}_{\mathrm{f}}=$ Fresh leaf weight; $\mathrm{V}_{\mathrm{S}}=$ volume of the supernatant; $\mathrm{V}_{\mathrm{T}}=$ Total volume of the mixture

\subsubsection{Total Chlorophyll content (TC)}

Total chlorophyll content was analyzed by Arnon (1949) method. Fresh leaves were extracted with acetone and then centrifugation was done. The absorbance at $645 \mathrm{~nm}$ and $663 \mathrm{~nm}$ was measured with spectrophotometer using the supernatant. Total chlorophyll was calculated by adding chlorophyll-a and chlorophyll-b as given below:

$$
\begin{aligned}
& \text { Chlorophyll-a }(\mathrm{mg} / \mathrm{g})=\left(\left(\mathrm{A}_{663} \times 12.7\right)-\left(\mathrm{A}_{645} \times 2.69\right)\right) \times \mathrm{V}_{\mathrm{T}} /\left(\mathrm{W}_{\mathrm{F}} \times 1000\right) \\
& \begin{aligned}
\text { Chlorophyll-b }(\mathrm{mg} / \mathrm{g}) & =\left(\left(\mathrm{A}_{645} \times 22.9\right)-\left(\mathrm{A}_{663} \times 4.68\right)\right) \times \mathrm{V}_{\mathrm{T}} /\left(\mathrm{W}_{\mathrm{F}} \times 1000\right) \\
\mathrm{TC}(\mathrm{mg} / \mathrm{g}) & =\text { Chlorophyll-a }+ \text { Chlorophyll-b }
\end{aligned}
\end{aligned}
$$

Where, A- Absorbance of the extract; $\mathrm{V}_{\mathrm{T}^{-}}$Total volume of the chlorophyll solution $(\mathrm{ml}) ; \mathrm{W}_{\mathrm{F}}$ - Fresh leaf weight $(\mathrm{g})$.

\subsection{Air Pollution Tolerance Index (APTI)}

APTI is a method for determining how sensitive and toleran plants are towards air pollution. This approach is reliable and easy for classifying plants according to their sensitivity to pollutants in the air. The biochemical factors that influence APTI values include $\mathrm{AA}, \mathrm{pH}, \mathrm{RWC}$, and $\mathrm{TC}$ content of plants (Krishnaveni, 2013).

Changes in these parameters can also be used as a sign of physiological damage and as a marker of air pollution for the initial identification of stress before the beginning of visible injury symptoms (Afridi et al., 2019). It was calculated by Singh and Rao method (Singh et al., 1991):

$$
\mathrm{APTI}=\frac{[\mathrm{AA}(\mathrm{TC}+\mathrm{pH})]+\mathrm{RWC}}{10}
$$

Where, AA- Ascorbic acid, TC- Total chlorophyll content, RWCRelative water content of leaves.

\subsection{Soil parameter analysis}

The soil samples were collected once from ten villages during the vegetative stage of rice and wheat. The samples were taken from two depths $(0-15 \mathrm{~cm}$ and $15-30 \mathrm{~cm})$ with the help of an auger. Soil samples were air-dried followed by grinding and sieving to $2 \mathrm{~mm}$ for further analysis. Physicochemical parameters such as $\mathrm{pH}$, electrical conductivity (EC), available nitrogen, available phosphorous, and available potassium of soil samples were analyzed. $\mathrm{pH}$ and $\mathrm{EC}$ were determined by using a $\mathrm{pH}$ meter and EC meter respectively. Available nitrogen was analyzed by the method of alkaline potassium permanganate (Subbaiah, 1956). Available phosphorous was analyzed by the Olsen method (Olsen et al., 1954). Available potassium in soil was extracted by ammonium acetate and then it was analyzed by using a Flame photometer by (Hanway \& Heidal, 1952).

\subsection{Statistical analysis}

At each location, the mean and standard deviation of triplicates of rice and wheat were calculated. Pearson's correlation coefficient (r) was calculated to find the relationship between APTI and its biochemical parameters. Results were statistically analyzed using two-way ANOVA. Linear regression analysis $\left(\mathrm{R}^{2}\right)$ was conducted to analyze the impact of air pollutants on APTI, $\mathrm{pH}$, relative water concentration, ascorbic acid, and total chlorophyll of crops. All the statistical analyses were performed using Microsoft excel.

\section{Result and Discussion}

\subsection{Air quality around Thermal Power Plant}

The concentration of $\mathrm{NO}_{\mathrm{x}}$, Ozone, $\mathrm{SO}_{\mathrm{x}}$, and $\mathrm{PM}_{10}$ were monitored in 10 different villages during the growth of rice and wheat. The concentration of $\mathrm{NO}_{2}$ ranged from 11.4 to $112.4 \mu \mathrm{g} / \mathrm{m}^{3}$ as shown in Figure 6. Sharma et al. (2021a) analyzed the concentration of $\mathrm{NO}_{\mathrm{x}}$ in Faridabad and reported up to $70 \mu \mathrm{g} / \mathrm{m}^{3}$. The highest concentration of $\mathrm{SO}_{2}$ during the growth of rice and wheat was found in Mujedi village while the lowest concentration was found in the control site. The concentration of $\mathrm{SO}_{2}$ did not exceed the NAAQS value $\left(80 \mu \mathrm{g} / \mathrm{m}^{3}\right)$. Sharma et al. (2019) studied the air pollution levels in different locations of Delhi and reported up to $35 \mu \mathrm{g} / \mathrm{m}^{3}$ of $\mathrm{SO}_{\mathrm{x}}$ and $121 \mu \mathrm{g} / \mathrm{m}^{3}$ of $\mathrm{NO}_{\mathrm{x}}$. The concentration of ozone ranged from 10.1 to $86.4 \mu \mathrm{g} / \mathrm{m}^{3}$. The concentration of $\mathrm{PM}_{10}$ ranged from 134.8 to $294.2 \mu \mathrm{g} / \mathrm{m}^{3}$. $\mathrm{PM}_{10}$ has been exceeded the NAAQS in all the sites (Figure 3). In a study of $\mathrm{PM}_{10}$ from 2001 to 2019 in Delhi, it was reported that the average concentration of $\mathrm{PM}_{10}$ was $227 \mu \mathrm{g} / \mathrm{m}^{3}$ which supports our findings (Sharma et al., 2021b). Korhale et al. (2021) reported the concentration of $\mathrm{NO}_{\mathrm{x}}$ up to $82.1 \mu \mathrm{g} / \mathrm{m}^{3}$ and the concentration of ozone up to $96.1 \mu \mathrm{g} / \mathrm{m}^{3}$ which is similar to our findings of air pollutants. 


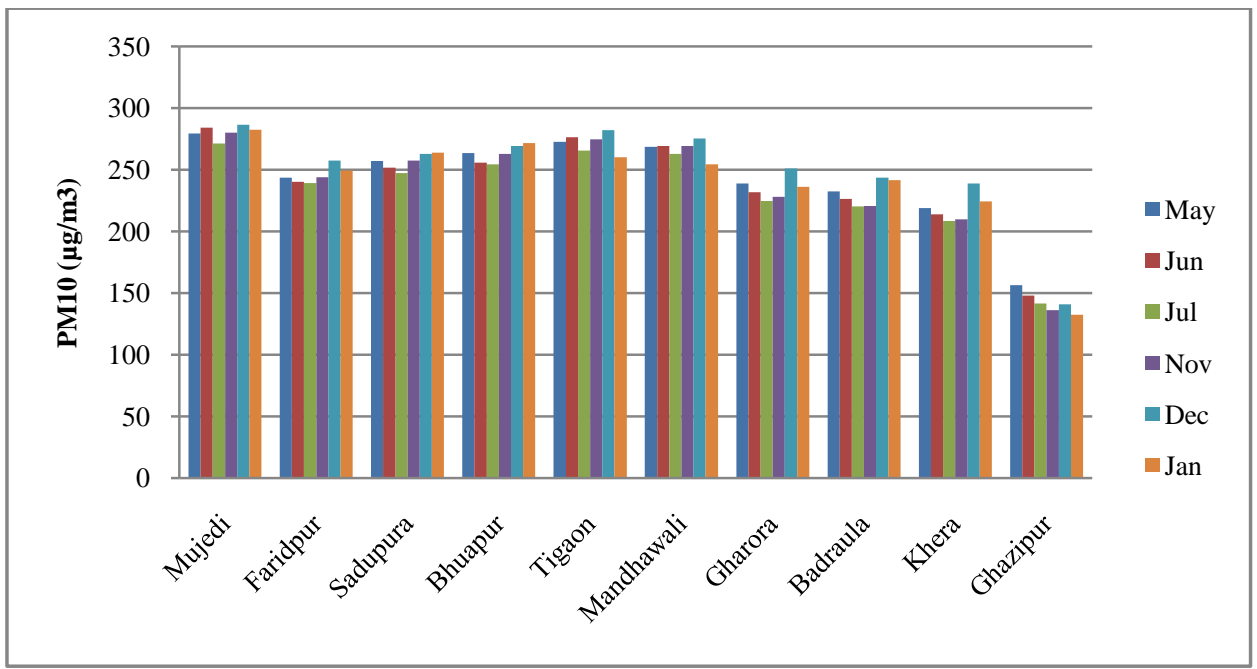

Figure 3 Concentration of $\mathrm{PM}_{10}$ at ten different sites

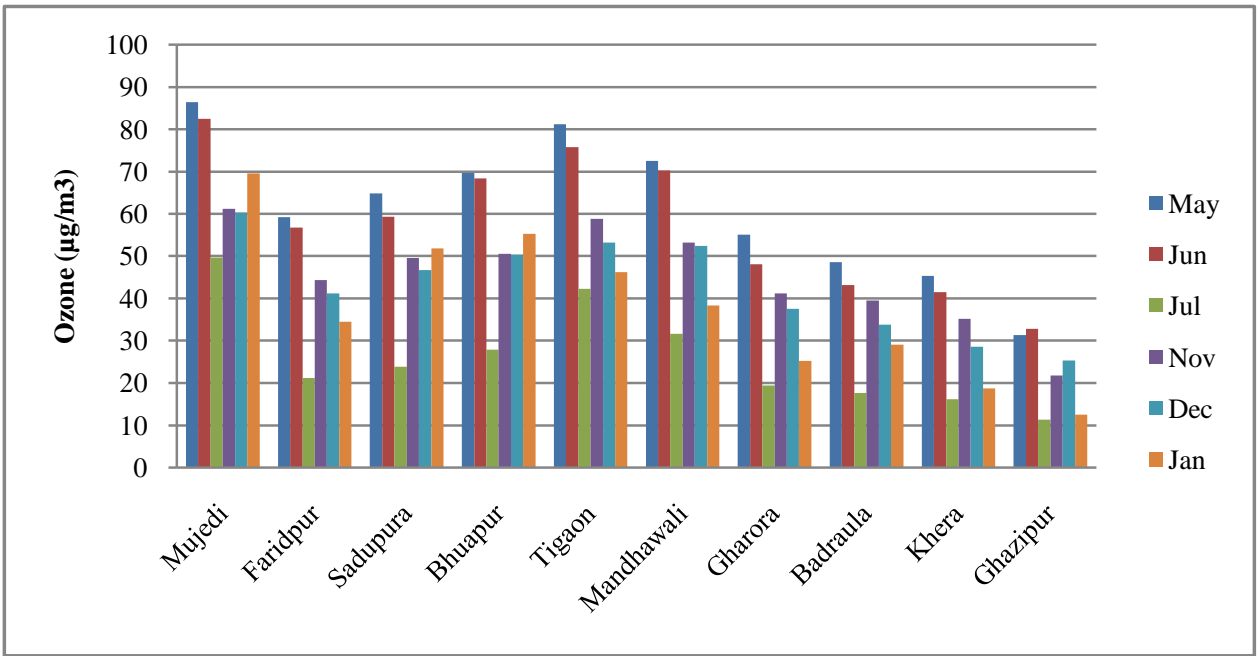

Figure 4 Concentration of ozone at ten different sites

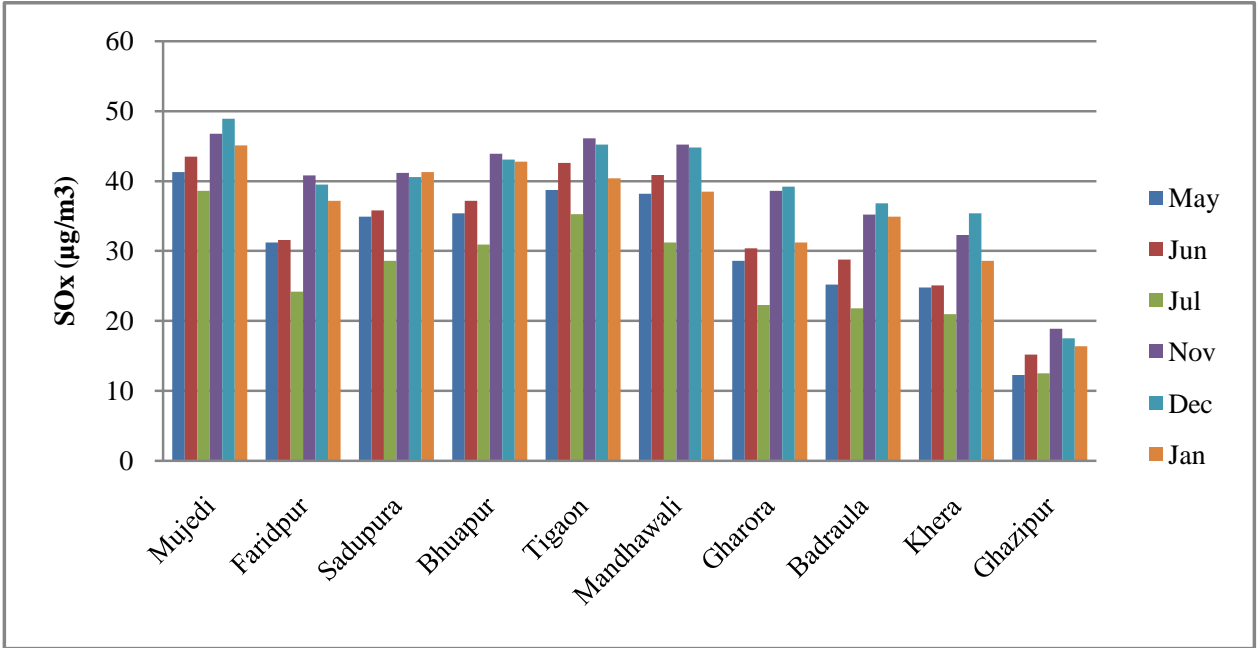

Figure 5 Concentration of $\mathrm{SO}_{\mathrm{x}}$ at ten different sites

Journal of Experimental Biology and Agricultural Sciences http://www.jebas.org 


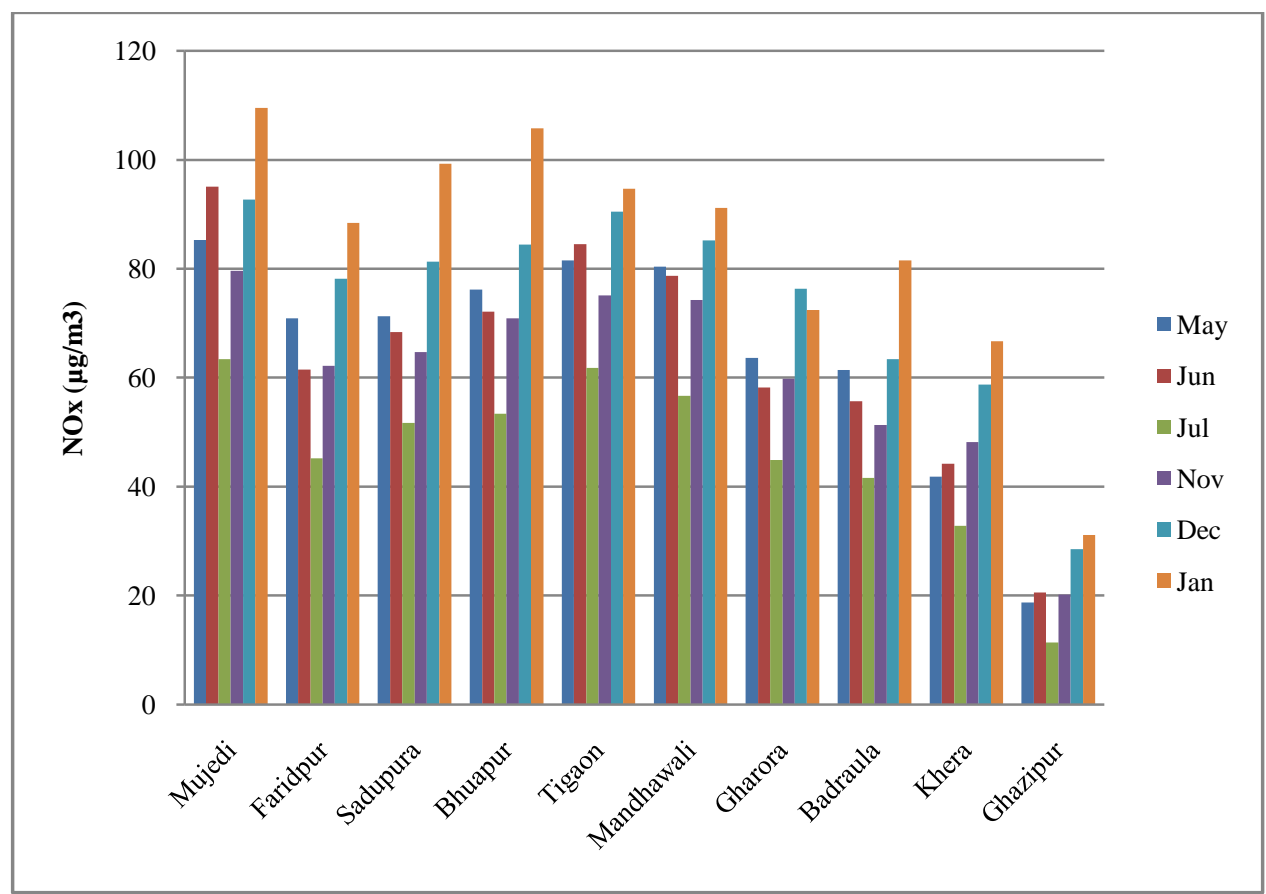

Figure 6 Concentration of $\mathrm{NO}_{\mathrm{x}}$ at ten different sites

Table 3 Average AQI values at different sites

\begin{tabular}{|c|cccccc|}
\hline Sites & Mujedi & Faridpur & Sadupura & Bhuapur & Tigaon \\
\hline Average AQI & 145.5 & 115.4 & 123.5 & 129.2 & 137.1 \\
\hline Sites & Mandawali & Gharora & Badraula & Khera & Ghazipur \\
\hline Average AQI & 130.1 & 106.8 & 102.4 & 90.4 & 33.2 \\
\hline
\end{tabular}

\subsection{Air Quality Index (AQI)}

The air quality index was calculated using $\mathrm{NO}_{2}, \mathrm{PM}_{10}$, and Ozone. Most of the sites are found to be moderately polluted while control sites have shown good air quality. Few villages like Gharora, Badraula, and Khera have satisfactory air quality in some of the months. Also, AQI during the growth of rice was more than the AQI during the growth of wheat. Sethi \& Mittal (2019) reported the AQI in the Faridabad region and the air quality was moderately polluted to very poor air quality. Sharma et al. (2019) assessed the ambient air quality in residential, commercial, and industrial areas of Faridabad and reported that the air quality was light to severely polluted.

\section{$3.3 \mathrm{pH}$}

The $\mathrm{pH}$ of crop samples ranged from 4.1 to 7.9. Maximum $\mathrm{pH}$ (7.9) was found in the rice sample from the Ghazipur control site while minimum $\mathrm{pH}$ (4.1) was found in a wheat sample from Mujedi. The $\mathrm{pH}$ of both crop samples was lowest in its maturity stage followed by the reproductive and vegetative stage (Figure 7).
The results show that acidic $\mathrm{pH}$ was found in high polluting areas while neutral or basic $\mathrm{pH}$ was found in control and low polluting areas. The acidic $\mathrm{pH}$ can be attributed to air pollutants like $\mathrm{NO}_{2}$, ozone, $\mathrm{SO}_{2}$, and particulate matter. Similar studies have reported that low pH is found in high pollution areas (Afridi et al., 2019). Sen et al. (2017) studied the $\mathrm{pH}$ of different plants in pre-monsoon and post-monsoon season and found acidic $\mathrm{pH}$ of plants in premonsoon season due to more air pollution. Also, the $\mathrm{pH}$ of plants increased post-monsoon since the air pollution washed off due to rainfall. Low $\mathrm{pH}$ disturbs the exchange of gases through stomata and hampers the photosynthetic rate of leaves while high $\mathrm{pH}$ is responsible for the increased conversion of hexose sugar to ascorbic acid that aids in tolerating the capacity of plants toward air pollutants (Joshi et al., 2011). Studies have shown that $\mathrm{pH}$ controls the physiological activity of plants (Singh et al., 1991). Some enzymes regulations are $\mathrm{pH}$-dependent for the biological activities of the organism (Karmakar \& Padhy, 2019). The photosynthetic efficiency is also controlled by $\mathrm{pH}$ and at low $\mathrm{pH}$, the efficiency gets reduced (Bharti et al., 2018). The plant is resistant to air pollutants at a neutral $\mathrm{pH}$, however, it is vulnerable to air pollution at a low $\mathrm{pH}$. 


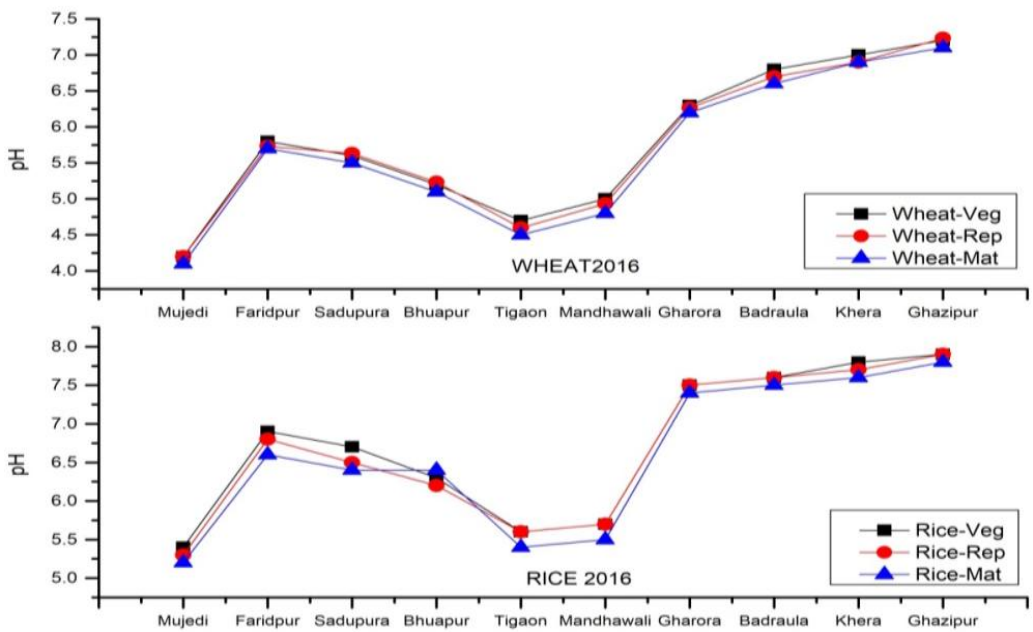

Figure $7 \mathrm{pH}$ values of rice and wheat in vegetative, reproductive and maturity phase at ten different study sites.

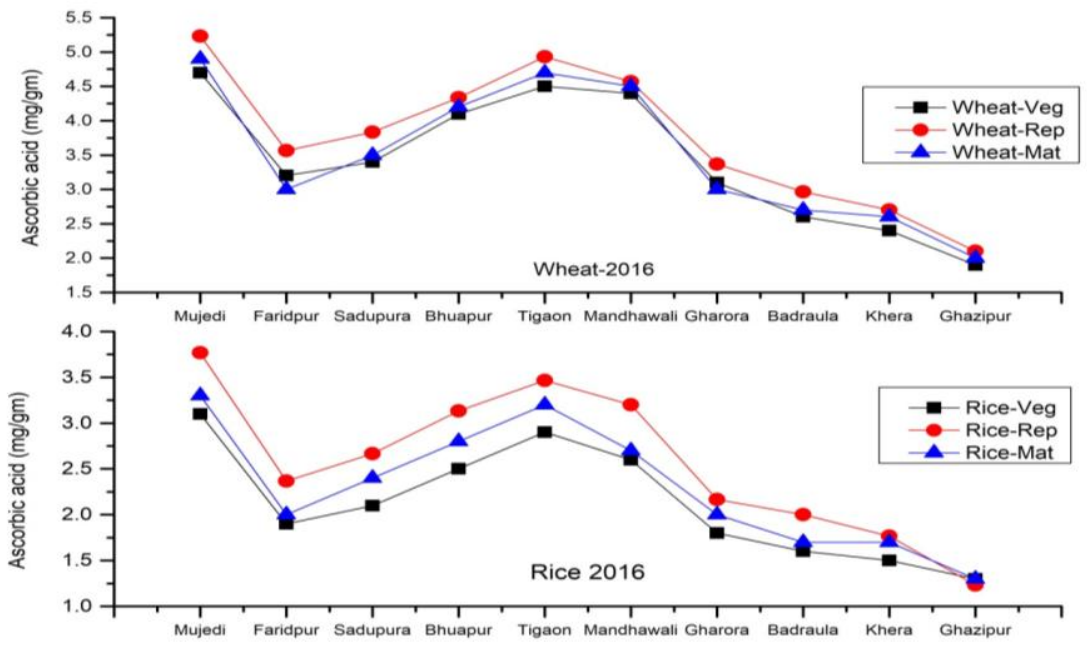

Figure 8 Ascorbic acid content (mg/g) of rice and wheat in vegetative, reproductive, and maturity phase

\subsection{Ascorbic acid}

The concentration of ascorbic acid in leaves at the vegetative, reproductive, and maturity stage of rice and wheat crop samples collected from 10 different sites have been shown in Figure 8. Wheat has a higher ascorbic acid concentration as compared to rice. Its value ranged from $1.2 \mathrm{mg} / \mathrm{g}$ to $3.1 \mathrm{mg} / \mathrm{g}$. Maximum ascorbic acid content was observed in Mujedi. This increase in concentration might be due to the high air pollution, the production of ascorbic acid increased to defense against air pollution. Minimum concentration was found at the control site due to low air pollution. In the reproductive stage of both crops, ascorbic acid concentration was found highest and the lowest concentration was observed in the vegetative stage. There is a significant difference in ascorbic acid in different sites due to variation in different levels of pollutants. The present study shows that a high concentration of ascorbic acid favors pollution tolerance with its defense mechanism whereas low concentration is due to its consumption while removing cytotoxic free radicals generated in chain reactions (Rai \& Panda, 2014). Results of this study were supported by the findings of Mina et al. (2018) where the concentration of ascorbic acid in rice varieties increased in elevated particulate matter (EPM) conditions. Ascorbic acid activates various major physiological processes in plants including cell division, synthesis of cell walls, and defense mechanism (Liu \& Ding, 2008). Being the most abundant watersoluble antioxidant, it is an important index for determining the tolerant capacity to several environmental pressures such as the stress of drought, heat, salt, etc (Zhang et al., 2016). It acts as a reducer and plays an important role in fixing photosynthesis with reducing ability directly related to its concentration. Its reducing activity is also pH-dependent (Bakiyaraj \& Ayappan, 2014). In the current study also, a high correlation is observed between $\mathrm{pH}$ and ascorbic acid. 


\subsection{Total chlorophyll content}

The amount of chlorophyll in a plant determines its photosynthetic activity, growth, and development. Total chlorophyll concentrations range from $0.82 \mathrm{mg} / \mathrm{g}$ to $9.7 \mathrm{mg} / \mathrm{g}$ (Figure 9). The chlorophyll content was reduced at the maturity stage of both crops rice and wheat. Rai \& Panda (2015) also reported that the stage of development and level of pollution is responsible for the variation of chlorophyll content from species to species. The total chlorophyll content of rice was higher as compared to wheat. This might be due to the high air pollution, blockage of the stomatal pores, and accumulation of pollutants on the leaf surface during the growth of wheat (Noor et al., 2015).

Air pollution results in the breakdown of photosynthetic pigments (Nayak et al., 2015). Chlorophyll is considered a stress metabolite and aids in the tolerance capacity of the plant to pollution
(Gholami et al., 2016). A high concentration of air pollutants causes the replacement of $\mathrm{Mg}^{+2}$ ions present in chlorophyll molecule with two hydrogen atoms and gets converted into to pheophytin molecule (Rahmawati et al., 2014). In the current study, high concentrations of $\mathrm{NO}_{2}$, ozone, and $\mathrm{PM}_{10}$ might have caused denaturation of chloroplast leading to a reduction in chlorophyll content in polluted sites as compared to the control site (Gupta et al., 2016). The concentration of chlorophyll may differ due to leaf age, species variation, level of pollution, and differences in conditions of biotic and abiotic (Katiyar \& Dubey, 2001)

\subsection{Relative water content (RWC)}

In the current study, RWC ranged from $53 \%$ to $92 \%$. The maximum RWC was recorded as $92 \%$ in the rice sample while the minimum was $53 \%$ for both rice and wheat (Figure 10). Higher
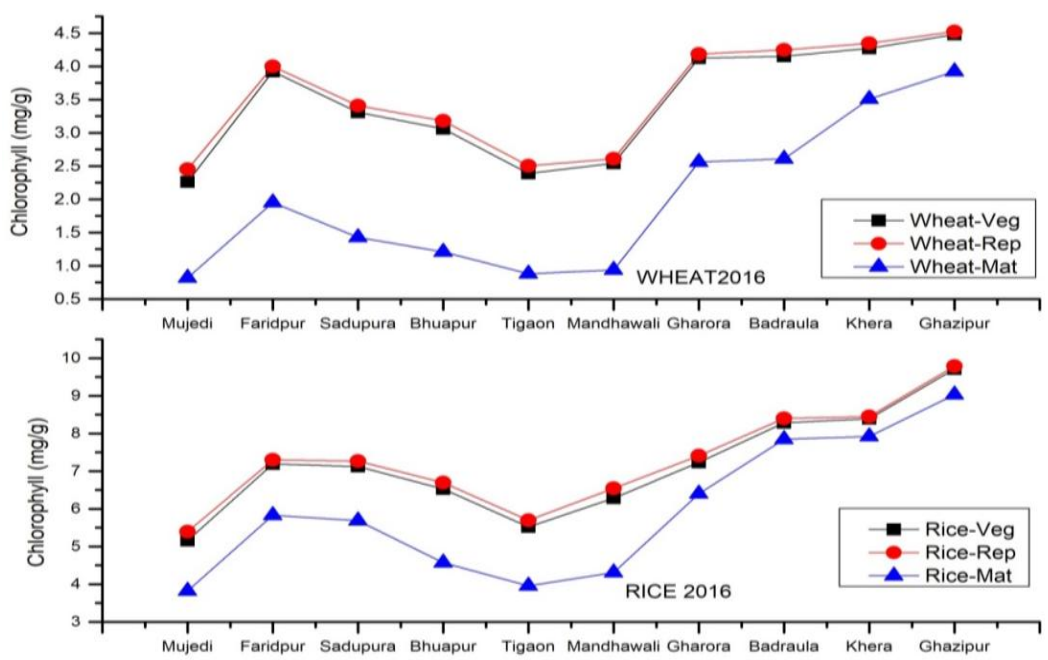

Figure 9 Chlorophyll content $(\mathrm{mg} / \mathrm{g})$ of rice and wheat in vegetative, reproductive, and maturity phase

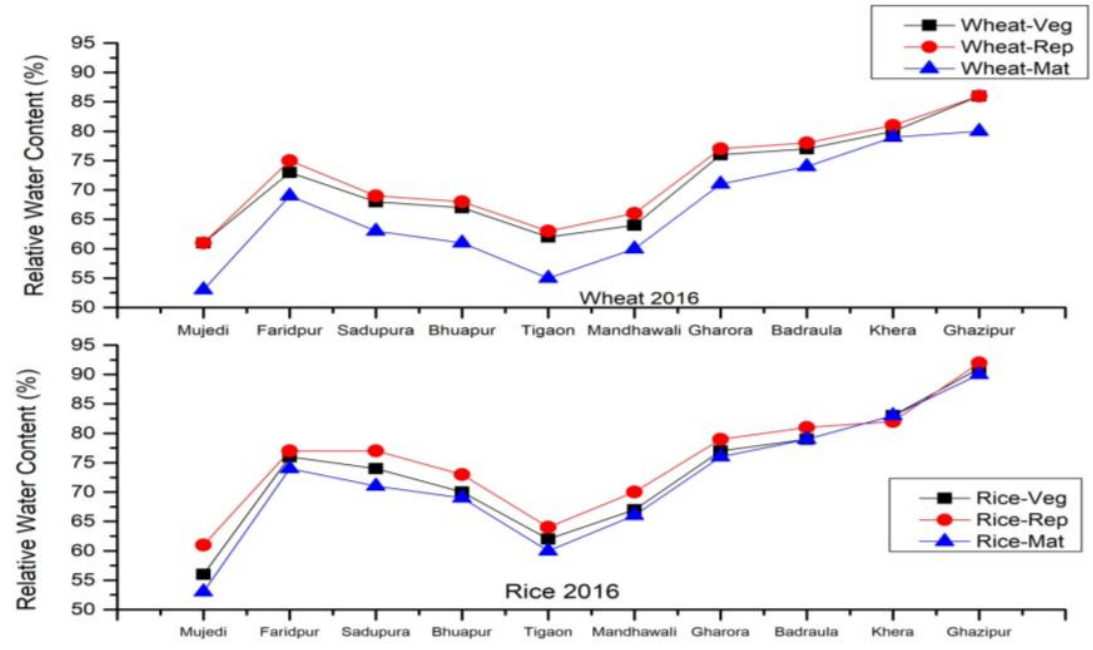

Figure 10 Relative water content (\%) of rice and wheat in vegetative, reproductive, and maturity phase at ten different study sites

Journal of Experimental Biology and Agricultural Sciences

http://www.jebas.org 
RWC helps in resisting the plant towards drought stress conditions (Pandey et al., 2016). A good amount of water in plants aids in maintaining the physiological balance of plants during stress such as air pollution (Lohe et al., 2015). The decrease in RWC in Mujedi was due to air pollution which increases the protoplasmic permeability affecting the loss of nutrients and water from leaves of the plant and thereby causing senescence (Manjunath \& Reddy, 2019). These pollutants disturb the water pulling route from roots to leaf hampering the rate of transpiration, cooling of the leaf, and transfer of minerals (Sen et al., 2017).

\subsection{Air Pollution Tolerance Index (APTI)}

In the APTI formula, AA $(\mathrm{TC}+\mathrm{pH})$ signifies the ability of chloroplast to fight against pollutants when it enters the plant. The addition of RWC in the formula represents the potential of the cell membrane to support its permeability under a polluted environment. The combination of four biochemical parameters provides the best index to determine the potentiality of plants under polluted conditions (Garg et al., 2015). APTI has three different categories for indicating the sensitivity of plants towards air pollution as shown in Table 4 (Singh et al., 1991).

The APTI of rice ranged from 8.28 to 11.38 . The most polluted site Mujedi showed minimum APTI while the control site Ghazipur showed maximum APTI values (Figure 11). In wheat, the APTI values ranged from 7.26 to 11.18 . In the reproductive phase of wheat, maximum APTI values were found while vegetative and maturity phases showed comparable APTI values. Rice and wheat fall in the sensitive category of APTI. In both years, rice has higher APTI than wheat. It means that rice is less sensitive to air pollution than wheat. The low value of APTI of wheat is due to the high pollution during the growth of the wheat crop. Tak \& Kakde (2020) examined the APTI of twelve plants in three industrial areas and control sites and found that APTI of all plants are lowered in industrial sites as compared to APTI in the control site. Javanmard et al. (2020) studied four deciduous plant species in Iran and observed that APTI of all species declined with increasing dust collection. These findings support our study where APTI was decreased near the power plant as compared to the control site. Molnar et al., 2020 reported that APTI of Celtis occidentalis was $9.5,14$, and 15 in industrial, urban, and rural areas respectively.

Table 4 Categories of APTI

\begin{tabular}{|cc|}
\hline APTI values & Plants Response \\
\hline$<11$ & Sensitive \\
\hline $12-16$ & Intermediate \\
\hline$>17$ & Tolerant \\
\hline
\end{tabular}

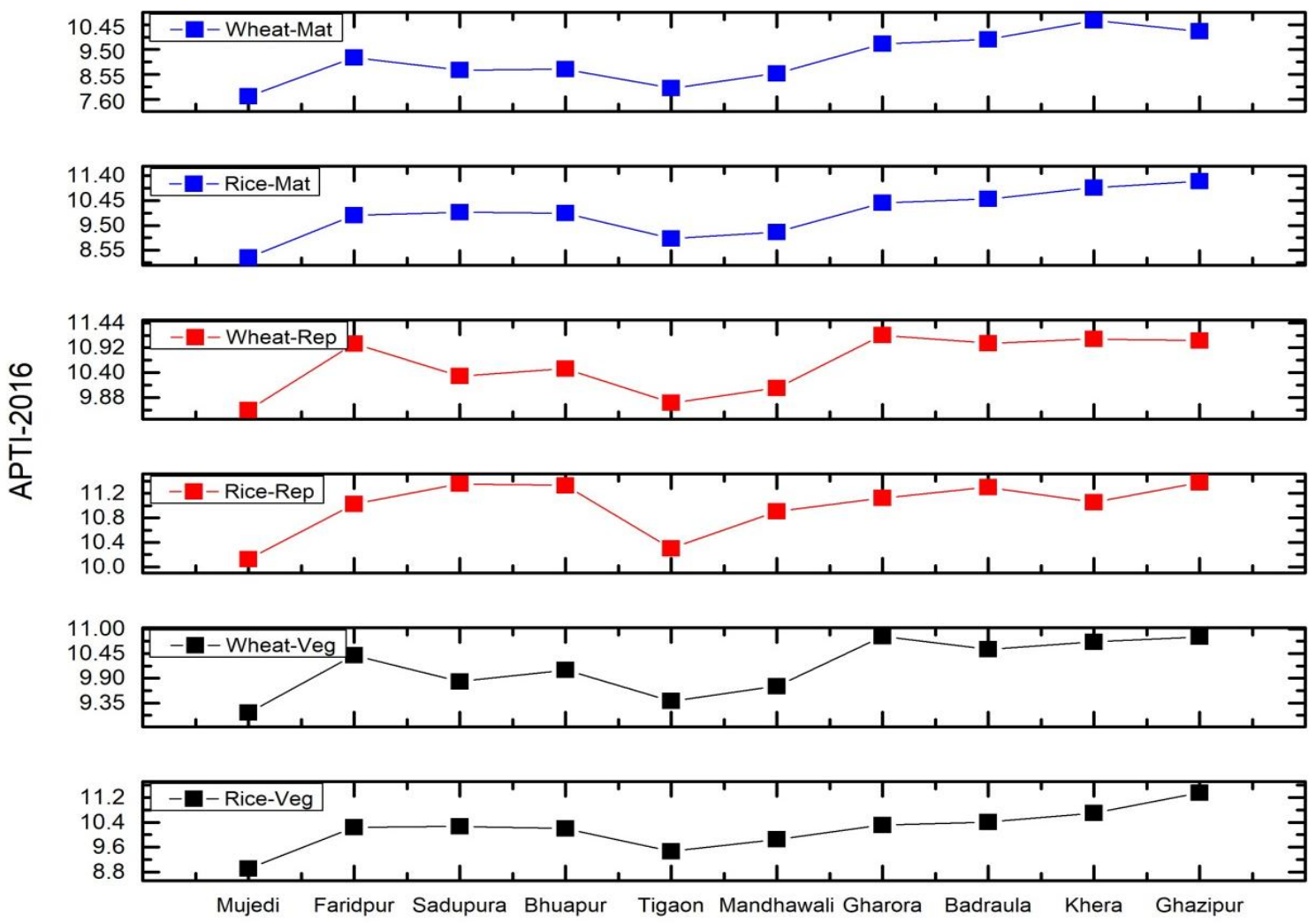

Figure 11 APTI values of rice and wheat in vegetative, reproductive, and maturity phase 
Table 5 Correlation of pH, RWC, AA, Chlorophyll and APTI in rice and wheat

\begin{tabular}{|c|c|c|c|c|c|}
\hline Rice & $\mathrm{pH}$ & RWC & $\mathrm{AA}$ & Chlorophyll & APTI \\
\hline $\mathrm{pH}$ & 1 & & & & \\
\hline RWC & 0.931 & 1 & & & \\
\hline $\mathrm{AA}$ & -0.973 & -0.975 & 1 & & \\
\hline Chlorophyll & 0.928 & 0.984 & -0.976 & 1 & \\
\hline APTI & 0.705 & 0.824 & -0.710 & 0.757 & 1 \\
\hline Wheat & $\mathrm{pH}$ & RWC & $\mathrm{AA}$ & Chlorophyll & APTI \\
\hline $\mathrm{pH}$ & 1 & & & & \\
\hline RWC & 0.976 & 1 & & & \\
\hline $\mathrm{AA}$ & -0.993 & -0.987 & 1 & & \\
\hline Chlorophyll & 0.963 & 0.965 & -0.963 & 1 & \\
\hline APTI & 0.913 & 0.926 & -0.905 & 0.969 & 1 \\
\hline
\end{tabular}

\subsection{Correlation of APTI with biochemical parameters}

The relationship between $\mathrm{pH}$, Relative Water Content (RWC), Ascorbic acid (AA), Chlorophyll, and APTI is shown in Table 5. In both rice and wheat, there is a high correlation between APTI and biochemical markers. A positive correlation was found in APTI and pH, RWC, and chlorophyll while a negative correlation was observed in APTI and ascorbic acid. Also, ascorbic acid shows a negative correlation with $\mathrm{pH}, \mathrm{RWC}$, and chlorophyll. Ascorbic acid is one of the best indications for air pollution stress since it has the highest correlation value with APTI. In both years, it is significant that APTI of wheat is more perfectly correlated with its biochemical parameters than rice. Various researchers have performed this correlation analysis of APTI with biochemical parameters (Zhang et al., 2020). Similar to our findings, Sahu et al. (2020) reported a positive correlation of APTI with total chlorophyll content and relative water content in trees. Yadav \& Pandey (2020) showed a negative correlation of ascorbic acid with total chlorophyll content in the Neem plant which supports our finding of negative correlation of ascorbic acid with chlorophyll.

\subsection{Soil analysis}

The results of soil samples indicate that the soil was basic and ranged from 6.6 to 8.7. The $\mathrm{pH}$ of the soil is an essential characteristic because it affects biological and chemical processes. The $\mathrm{pH}$ of the soil varied from 6.56 to 8.7 , with a mean value of 7.54. The soil is alkaline, ranging from neutral to slightly alkaline. Soil provides a variety of nutrients that are necessary for plant growth. The availability of nutrients in the soil is affected by changes in soil pH. Electric conductivity was 0.204 to $0.393 \mathrm{mmohs} / \mathrm{cm}$. The amount of salt in agricultural soil is measured in EC. Salinity in the soil is explained by variations in
EC caused by varying salt concentrations. In non-saline soil, variations in EC are caused by the cation exchange capacity, composition, and texture of the soil. The soil is non-saline since the EC values are less than $2.000 \mathrm{mS} / \mathrm{cm}$. Available nitrogen ranged from 112 to $288 \mathrm{~kg} / \mathrm{hectare}$. Most of the soil had a moderate amount of available nitrogen while in some seasons for a few villages, the nitrogen level was in a low category. Available phosphorous ranged from 20.5 to $39.7 \mathrm{~kg} /$ hectare. Phosphorus is one of the most important nutrients for the majority of crops since it is required for maximum crop production. Phosphorus levels in soil range from moderate to high. The average value of potassium in all sites in different months was found to be $191 \mathrm{~kg} / \mathrm{hectare}$. All the potassium values were in the medium category of potassium in the soil. The maximum value was found to be $210.5 \mathrm{~kg} /$ hectare and the minimum value was $170.6 \mathrm{~kg} / \mathrm{hectare}$.

\subsection{Linear regression analysis}

Linear regression analysis was performed between Air Quality Index (AQI) and $\mathrm{pH}$, relative water content, ascorbic acid, chlorophyll content, and APTI (Table 6). Regressor value $\mathrm{r}^{2}$ represents the impact of an independent variable (AQI) on the dependent variable (physiological parameters). In the reproductive stage, the $r^{2}$ value was less than 0.5 which shows there was a weak to moderate effect of air pollutants on APTI of rice and wheat crops. Moderate effect of air pollutants was also observed in $\mathrm{pH}$, ascorbic acid, chlorophyll content, and APTI in some of the stages of rice and wheat. The substantial effect of air quality was observed in $\mathrm{pH}$ values of rice and wheat crops since the $r^{2}$ value was greater than 0.75 in both crops. The $r^{2}$ values of relative water content was close to 1 which represents the strong impact of air pollutants on the relative water content in the leaves of rice and wheat crop. 
Table 6 Linear regression analysis $\left(\mathrm{r}^{2}\right)$ of $\mathrm{pH}$, Relative water content, ascorbic acid, chlorophyll content, APTI with Air Quality Index (AQI)

\begin{tabular}{|cccc|ccc|}
\hline \multirow{2}{*}{ Crop } & Phases & $\mathrm{pH}$ & Relative water content & Ascorbic acid & Chlorophyll content & APTI \\
\hline \multirow{2}{*}{ Rice } & Vegetative & 0.7636 & 0.9014 & 0.6397 & 0.7162 & 0.7884 \\
\cline { 2 - 7 } & Reproductive & 0.8449 & 0.9439 & 0.8444 & 0.7971 & 0.4859 \\
\cline { 2 - 7 } & Maturity & 0.6886 & 0.8969 & 0.7775 & 0.6829 & 0.6786 \\
\hline \multirow{2}{*}{ Wheat } & Vegetative & 0.8318 & 0.8626 & 0.7501 & 0.7673 & 0.7249 \\
\cline { 2 - 7 } & Reproductive & 0.7639 & 0.7656 & 0.7548 & 0.6807 & 0.4846 \\
\cline { 2 - 7 } & Maturity & 0.7409 & 0.7482 & 0.7532 & 0.835 & 0.6348 \\
\hline
\end{tabular}

Table 7 Two-way ANOVA summary table for $\mathrm{pH}$, relative water content (R), total chlorophyll content (T), and ascorbic acid content (A) of plant species understudy

\begin{tabular}{|c|c|c|c|}
\hline \multirow{2}{*}{ Parameter } & \multicolumn{3}{|c|}{ P-value } \\
\hline & Sites & Crop & Sites $\times$ Crop \\
\hline $\mathrm{pH}$ & $0.0112 *$ & $4.17 \mathrm{e}-14 * * *$ & $0.0141 *$ \\
\hline RWC & $0.000979 * * *$ & $6.78 \mathrm{e}-09 * * *$ & $0.875^{\mathrm{ns}}$ \\
\hline Chlorophyll & $0.933(\mathrm{~ns})$ & $2 \mathrm{e}-16 * * *$ & $2.04 \mathrm{e}-08 * * *$ \\
\hline AA & $0.258^{\mathrm{ns}}$ & $1.21 \mathrm{e}-12 * * *$ & $0.0477 *$ \\
\hline APTI & $0.0152 *$ & $5.96 \mathrm{e}-11 * * *$ & $0.307^{\mathrm{ns}}$ \\
\hline
\end{tabular}

\# AA ascorbic acid, RWC relative water content; ‘*’ ‘**’ and ‘***' denotes significant at $5 \%, 1 \%$, and $0.01 \%$ level of significance, respectively.

\subsection{Two-way ANOVA analysis}

Two-way repeated measures ANOVA was performed for 4 biochemical parameters, where the effect of site, crop (rice and wheat), and interaction between sites and crop were tested using $\mathrm{F}$ statistics. In Table 7, p-values were given to show factors significantly different or not. For $\mathrm{pH}$, it was observed that over the sites it was significantly different, over the crops also significantly different and interaction between site and crop was also significant. For RWC sites and crops are significantly varied but no significant interaction between sites and crops. For chlorophyll, sites are not significantly different while crops showed significant differences, and interaction between sites and crops also varied. For ascorbic acid except sites are not significantly different but crops and interaction between crop and sites are significantly different. The APTI value was significantly different over the sites and the APTI of crops like wheat and rice were also significantly different (Table 7.

\section{Conclusion}

The air quality index in ten villages ranged from moderately polluted to good air quality. Gas based thermal power plants are better than coal based thermal power plants since they release fewer air pollutants. To assess the sensitivity of crops towards the air pollution level, APTI is a well-known and excellent approach. This study revealed that crops (rice and wheat) are very sensitive towards air pollution and also helped in concluding that there is variation in values of biochemical parameters of both the crops at different selected sites due to variation in stress conditions of air pollution. High air pollution areas have lower APTI while low air pollution resulted in high APTI. The category of APTI of rice and heat are sensitive in all the sites and APTI has not fallen in the intermediate category in low air pollution sites. This research may be expanded for other crops in different stress conditions or polluted sites so that it can find out the suitability of crops according to their sensitivity to air pollution. Also, in future research, a mathematical model can be developed to identify and correlate the direct impacts of air pollutants on APTI. This model will help in designing the plantation and the suitable crop to be grown in different areas. Another recommendation from current research would be that standard values of APTI for different plants and crops should be developed so that it is helpful for future research by providing reference values of APTI. In the present scenario, diversified agriculture can be a sustainable option for the farmers to maintain their productivity and income.

\section{Declaration of interest}

There is no conflict of interest.

\section{Acknowledgment}

The authors are grateful to the Indian Agricultural Research Institute (I.A.R.I., Delhi) for supporting our work and providing all 
the facilities to conduct the research. This research was funded by National Thermal Power Plant (N.T.P.C., Faridabad).

\section{Ethical approval}

Not Applicable.

\section{Consent to Participate}

Not Applicable.

\section{Consent to Publish}

Not Applicable.

\section{Authors Contributions}

PC conducted the study and analyzed the samples. SAK collected the samples and interpreted the results. ASK edited the manuscript. SK analyzed the samples and interpreted the results. LC performed the statistical analysis of the data.

\section{Funding}

The study was funded by National Thermal Power Plant (N.T.P.C., Faridabad).

\section{Availability of data and materials}

Not applicable.

\section{References}

Achakzai K, Khalid S, Adrees M, Bibi A, Ali S, Nawaz R, Rizwan M (2017) Air pollution tolerance index of plants around brick kilns in Rawalpindi. Pakistan. Journal of Environmental Management 190: 252-258.

Afridi SG, Islam N, Shams DF, Shams S, Khan A, Shah M, Khan W, Shah M, Islam M, Iqbal A (2019) Assessment of air pollution tolerance of selected trees and crop species using biochemical and physiological analyses. Fresenius Environmental Bulletin 28(6): 4805-4810.

Arnon DI (1949) Copper enzymes in isolated chloroplasts. Polyphenoloxidase in Beta vulgaris. Plant Physiology 24(1): 1-15. DOI: $10.1104 /$ pp.24.1.1.

Bakiyaraj R, Ayyappan D (2014) Air pollution tolerance index of some terrestrial plants around an industrial area. International Journal of Modern Research and Reviews 2(1): 1-7.

Bharti SK, Trivedi A, Kumar N (2018)Air pollution tolerance index of plants growing near an industrial site. Urban Climate 24: 820-829.
Bui HT, Odsuren U, Kwon KJ, Kim SY, Yang JC, Jeong NR, Park BJ (2021) Assessment of Air Pollution Tolerance and Particulate Matter Accumulation of 11 Woody Plant Species. Atmosphere 12(8): 1067.

Chauhan A, Joshi PC (2010)Effect of ambient air pollutants on wheat and mustard crops growing in the vicinity of urban and industrial areas. New York Science Journal 3(2): 52-60.

CPCB Guideline for the measurement of ambient air pollutants (2011). Retrive from http://indiaenvironmentportal.org.in/files/ NAAQSManualVolumeI-1.pdf.

Garg A, Kumar A, Gupta NC (2021) Comprehensive study on impact assessment of lockdown on overall ambient air quality amid COVID-19 in Delhi and its NCR, India. Journal of Hazardous Materials Letters 2. https://doi.org/10.1016/ j.hazl.2020.100010.

Garg A, Saxena P, Ghosh C (2015) Evaluation of tolerance and sensitivity of selected plant species with special reference to gasoline exhaust pollution. International Journal of Scientific \& Technology Research 4(2): 199-207.

Gholami A, Mojiri A, Amini H (2016) Investigation of the air pollution tolerance index (APTI) using some plant species in Ahvaz region. The Journal of Animal and Plant Sciences 26(475): 480 .

Gupta GP, Kumar B, Kulshrestha UC (2016) Impact and pollution indices of urban dust on selected plant species for green belt development: mitigation of the air pollution in NCR Delhi, India. Arabian Journal of Geosciences 9(2): 136.10.1007/s12517015-2226-4.

Hanway JJ, Heidel H (1952) Soil analysis methods as used in Iowa state college soil testing laboratory. Iowa Agriculture 57:1-31.

Jacobs M, Hochheiser S (1958) Continuous sampling and ultramicrodetermination of nitrogen dioxide in air. Analytical Chemistry 30(3):426-428.

Javanmard Z, Kouchaksaraei MT, Hosseini SM, Pandey AK (2020) Assessment of anticipated performance index of some deciduous plant species under dust air pollution. Environmental Science and Pollution Research 27(31):38987-9. DOI: https://doi.org/10.1007/s11356-020-09957-w.

Joshi N, Bora M, Haridwar U (2011) Impact of air quality on physiological attributes of certain plants. Report and Opinion $3(2): 42-47$

Karmakar D, Padhy PK (2019) Air pollution tolerance, anticipated performance, and metal accumulation indices of plant species for 
greenbelt development in urban industrial area. Chemosphere 237:124522.

Katiyar V, Dubey PS (2001) Sulphur dioxide sensitivity on two stages of leaf development in a few tropical tree species. Indian Journal of Environment and toxicology 11(2):78-81.

Keller T, Schwager H (1977) Air pollution and ascorbic acid. European Journal of Forest Pathology 7(6):338-350.

Korhale N, Anand V, Beig G (2021) Disparity in ozone trends under COVID-19 lockdown in a closely located coastal and hillocky metropolis of India. Air Quality, Atmosphere \& Health 14(4):533-542.

Krishnaveni M (2013) Air pollution tolerance index and antioxidant activity of Partheniumhysterophorus. Journal of Pharmacy Research 7(4): 296-298.

Kuddus M, Kumari R, Ramteke PW (2011) Studies on air pollution tolerance of selected plants in Allahabad city, India. Journal of Environmental Research and Management 2(3): 42-46.

Liu YJ, Ding HU (2008) Variation in air pollution tolerance index of plants near a steel factory: Implication for landscape-plant species selection for industrial areas. WSEAS Transactions on Environment and development 4(1):24-32.

Lohe RN, Tyagi B, Singh V, Kumar TP, Khanna DR, Bhutiani R (2015) A comparative study for air pollution tolerance index of some terrestrial plant species. Global Journal of Environmental Science and Management 1(4): 315-324.

Malav LC, Khan SA, Kumar S, Gupta N, Chaudhary P (2017) Effect of air pollutants on growth and yield of rice (Oryza sativa) and wheat (Triticum aestivum) crops around the coal based thermal power plant. International Journal of Current Microbiology and Applied Sciences 6(10):3151-3165.

Manjunath BT, Reddy J (2019) Comparative evaluation of air pollution tolerance of plants from polluted and non-polluted regions of Bengaluru. Journal of Applied Biology and Biotechnology 7:63-68.

Mina U, Chandrashekara TK, Kumar SN, Meena MC, Yadav S, Tiwari S, Singh D, Kumar P, Kumar R (2018) Impact of particulate matter on basmati rice varieties grown in Indo-Gangetic Plains of India: Growth, biochemical, physiological and yield attributes. Atmospheric Environment 188:174-84.

Molnár VÉ, Tőzsér D,Szabó S, Tóthmérész B, Simon E (2020) Use of leaves as bioindicator to assess air pollution based on composite proxy measure (APTI), dust amount and elemental concentration of metals. Plants 9(12):1743.
Musselman RC, Lefohn AS, Massman WJ, Heath RL (2006) A critical review and analysis of the use of exposure-and flux-based ozone indices for predicting vegetation effects. Atmospheric Environment 40(10):1869-1888.

Nayak D, Patel DP, Thakare HS, Satasiya K, Shrivastava PK (2015) Assessment of air pollution tolerance index of selected plants. Indian Forester 141(4):372-378.

Noor MJ, Sultana S, Fatima S, Ahmad M, Zafar M, Sarfraz M, Balkhyour MA, Safi SZ, Ashraf MA (2015) RETRACTION: Estimation of Anticipated Performance Index and Air Pollution Tolerance Index and of vegetation around the marble industrial areas of Potwar region: bioindicators of plant pollution response. Environmental Geochemistry and Health volume 37: 441-455.

Olsen SR (1954) Estimation of available phosphorus in soils by extraction with sodium bicarbonate. Washington, D.C. : U.S. Department of Agriculture, 1954.

Pandey AK, Pandey M, Tripathi BD (2016) Assessment of Air Pollution Tolerance Index of some plants to develop vertical gardens near street canyons of a polluted tropical city. Ecotoxicology and Environmental Safety 134:358-364.

Rahmawati N, Rosmayati D, Basyuni M (2014) Chlorophyll content of soybean as affected by foliar application of ascorbic acid and inoculation of arbuscularmycorrhizal fungi in saline soil. International Journal of Scientific and Technology Research $3(7): 127-131$

Rai PK, Panda LL (2014) Dust capturing potential and air pollution tolerance index (APTI) of some road side tree vegetation in Aizawl, Mizoram, India: an Indo-Burma hot spot region. Air Quality, Atmosphere \& Health 7(1):93-101.

Rai PK, Panda LS (2015) Roadside plants as bio indicators of air pollution in an industrial region, Rourkela, India. International Journal of Advanced Research 4(1):14-36.

Rao MN, Rao HNV (1998) Air pollution. Tata McGraw Hill Publishing Company Limited, New Delhi.

Sahu C, Basti S, Sahu SK (2020) Air pollution tolerance index (APTI) and expected performance index (EPI) of trees in sambalpur town of India. SN Applied Sciences 2(8):1-4.

Sen A, Khan I, Kundu D, Das K, Datta JK (2017) Ecophysiological evaluation of tree species for biomonitoring of air quality and identification of air pollution-tolerant species. Environmental Monitoring and Assessment 189(6):262.

Sethi JK, Mittal M (2019) Ambient Air Quality Estimation using Supervised Learning Techniques. EAI Endorsed Transactions on 
Scalable Information Systems Retrieve from Subbaiah BV (1956) A rapid procedure for estimation of available https://pdfs.semanticscholar.org/be11/f357250dae9ede37e69f71d2 876938c91a12.pdf. nitrogen in soil. Current Science 25: 259.

Sharma N, Singh R, Rojoria YK, Rajendra P, Boadh R (2021a) Coupled WRF-AERMOD modeling system by using Dispersion of Air Pollutant and Generation of Gridded Emission Inventory of NOX over Faridabad and Gurugram. International Journal of Scientific Research in Mathematical and Statistical Sciences 8(1): $1-12$.

Sharma R, Kumar R, Sharma DK, Priyadarshini I, Pham BT, Bui DT, Rai S (2019) Inferring air pollution from air quality index by different geographical areas: case study in India. Air Quality, Atmosphere \& Health 12(11):1347-1357.

Sharma SK, Banoo R, Mandal TK (2021b) Seasonal characteristics and sources of carbonaceous components and elements of PM10 (2010-2019) in Delhi, India. Journal of Atmospheric Chemistry 26:1-20.

Singh A (1977) Practical plant physiology. Kalyani Publishers, New Delhi Pp. 266.

Singh SK, Rao DN, Agrawal M, Pandey J, Naryan D (1991) Air pollution tolerance index of plants. Journal of Environmental Management 32(1):45-55.

Sisodia A, Dutta S (2016) Air pollution tolerance index of certain plant species: a study of national highway no-8, India. Journal of Environmental Research and Development 10(4):723.

Tak AA, Kakde UB (2020) Evaluation of air pollution tolerance and performance index of plants growing in industrial areas. International Journal of Ecology and Environmental Science 2(1):1-5.

West PW, Gaeke GC (1956) Fixation of sulfur dioxide as disulfitomercurate (II) and subsequent colorimetric estimation. Analytical Chemistry 28(12):1816-9. DOI:https://doi.org/10.1021/ ac60120a005.

WHO ambient (outdoor) air quality database summary results (2018) Retrieve from https://www.who.int/airpollution/data/ AAP_database_summary_results_2018_final2.pdf?ua=1.

Yadav R, Pandey P (2020) Assessment of Air Pollution Tolerance Index (APTI) and Anticipated Performance Index (API) of roadside plants for the development of greenbelt in urban area of Bathinda City, Punjab, India. Bulletin of Environmental Contamination and Toxicology 105(6):906-914.

Zhang PQ, Liu YJ, Chen X, Yang Z, Zhu MH, Li YP (2016) Pollution resistance assessment of existing landscape plants on Beijing streets based on air pollution tolerance index method. Ecotoxicology and Environmental Safety 132:212-23.

Zhang W, Zhang Y, Gong J, Yang B, Zhang Z, Wang B, Zhu C, Shi J, Yue K (2020) Comparison of the suitability of plant species for greenbelt construction based on particulate matter capture capacity, air pollution tolerance index, and antioxidant system. Environmental Pollution 263:114615.

Journal of Experimental Biology and Agricultural Sciences http://www.jebas.org 